\title{
MYCOFLORA ASSOCIATED WITH FRUIT ROT OF CUSTARD APPLE (ANNONA SQUAMOSA L.)
}

\author{
Shamim Shamsi* and Sarowar Hosen \\ Department of Botany, University of Dhaka, Dhaka-1000, Bangladesh
}

Custard apple (Annona squamosa L.) showing fruit rot symptom was studied. A total of four fungal species were found to be associated with fruit rot of custard apple. The associated fungi were Alternaria alternata (Fr.) Kerissler, Colletotrichum orbiculare (Berk. \& Mont.) Arx., Fusarium Link. and Lasidiodiplodia theobromae (Pat.) Griff. \& Maubl. Out of four fungal species Lasidiodiplodia theobromae showed the highest (34) frequency whereas Alternaria alternata showed the lowest (10) frequency percentage of association.

Annona squamosa L. is the most widely grown species of Annona and belongs to the family Annonaceae (Ahmed et al. 2008). It is known as sugar apple, custard apple, Ata, Sharifa, etc. In Bangladesh common name of the fruit is Ata. Custard apple is high in energy, an excellent source of vitamin $\mathrm{C}, \mathrm{B}_{2}, \mathrm{~B}_{3}, \mathrm{~B}_{5}, \mathrm{~B}_{6}, \mathrm{~B}_{9}$ and thiamine and provides manganese, iron, magnesium, phosphorus and potassium in fair quantities. Heat-extracted oil from the seeds has been employed against agricultural pests. In past custard apple was considered as hardy crop devoid of any disease and pest. Among the various diseases, fungal diseases play an important role to severe loss of custard apple production. Major fungal diseases are anthracnose (Colletotrichum gloeosporioides), alternaria leaf spot (Alternaria spp.), cylindrocladium leaf spot (Cylindrocladium colhounii and Cylindrocladium scoparium), botryodiplodia rot (Botryodiplodia theobromae), black canker (Phomopsis anonacearum) and gliocladium rot (Gliocladium roseum) (Snowden 2008). Anthracnose is the most destructive diseases of custard apple. About 60 - 70 per cent losses have been reported due to the disease (Gaikwad et al. 2005). So far there is no report available regarding fruit rot disease of $A$. squamosa in Bangladesh. Present investigation was undertaken to find out the association of mycoflora with fruit rot of custard apple.

Annona squamosa showing fruit rot symptom was collected from the Kachukhet Bazar, Dhaka Cantonment, Dhaka during January to March, 2016. Samples were collected in separate sterile polyethylene bags, labeled properly and then brought to the laboratory. The fungi associated with samples were isolated following "Tissue planting method" on PDA medium. Percentage frequency of the occurrence of the fungal isolate was calculated by adopting the formula of Spurr and Wetly (1972):

$$
\% \text { frequency }=\frac{\text { Total no. of inocula from which a fungal isolate was observed }}{\text { Total no. of inocula }} \times 100
$$

*Author for correspondence: <prof.shamsi@gmail.com>. 
Morphological structures of the fungi were drawn in detail by the aid of Camera Lucida. Identification of the isolates was determined following the standard literatures (Booth 1971, Ellis1971, Barnet and Hunter 1972, Sutton 1980).

A total of four species of fungi were found to be associated with rotted fruits of custard apple. The isolated fungi were Alternaria alternata (Fr.) Kerissler, Colletotrichum orbiculare (Berk. \& Mont.) Arx., Fusarium Link. and Lasidiodiplodia theobromae (Pat.) Griff. \& Maubl. (= Botryodiplodia theobromae).

Fig. 1 showed that out of four fungi associated with custard apple the frequency percentage of association of Lasidiodiplodia theobromae was highest (34) followed by Fusarium sp. (30), Colletotrichum orbiculare (26) and Alternaria alternata (10).

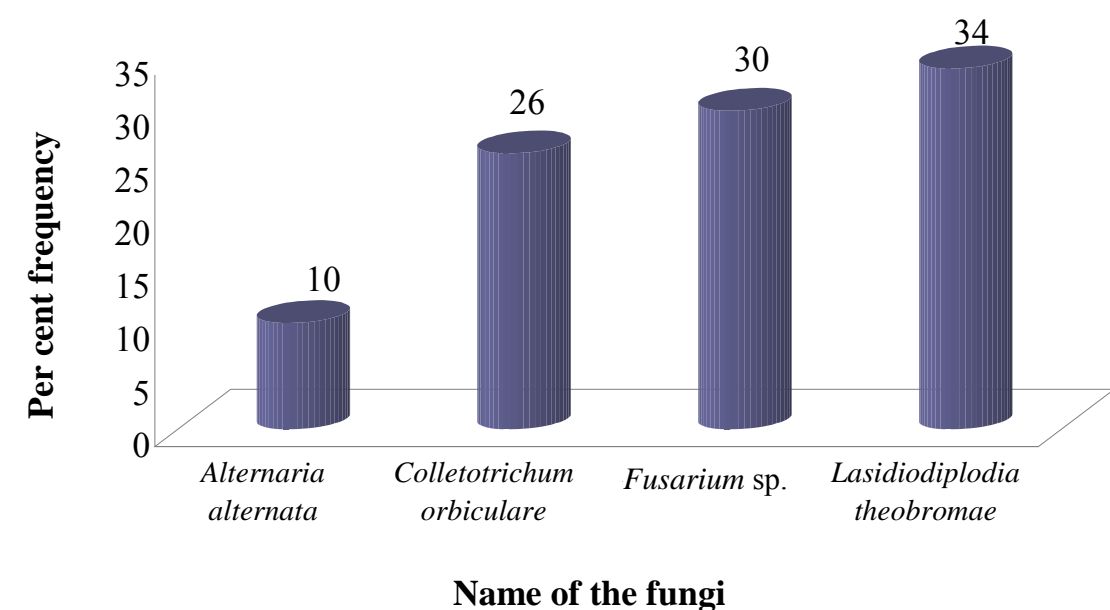

Fig. 1. Frequency percentage of association of fungi with fruit rot of custard apple.

\section{Taxonomic enumeration of fungal taxa associated with fruit rot of custard apple}

1. Alternaria alternata (Fr.) Kerissler, Beih. Bot. Zbl., 29: 434 (1912).

(Fig. 2Aa-2Ab)

Colonies olivaceous black, reverse black. Conidiophores arising singly from hyphae, pale to mid brown, straight or flexuous, smooth, up to $54 \mu \mathrm{m}$ long, $3-5 \mu \mathrm{m}$ thick. Conidia pale to mid golden brown, cattenulate, obclavate, obpyriform, ovoid or ellipsoidal, often with short cylindrical beak, smooth, up to 8 transverse, usually several longitudinal or oblique septa, mostly 19-37 $\times 9-8$ $\mu \mathrm{m}$, beak pale, $2-5 \mu \mathrm{m}$ thick. 
2. Colletotrichum orbiculare (Berk. \& Mont.) Arx., Verh. Akad. Wet. Amst. 51(3): 112 (1957).

(Fig. 2Ba)

Colonies with abundant white greyish aerial mycelium, reverse dark brown. Acervulus present, 20 - $30 \mu \mathrm{m}$ wide. Conidiophores hyaline, short. Setae present. Conidia straight, cylindrical obtuse at the apices, $12-16.2 \times 3.6-6 \mu \mathrm{m}$.

\section{Fusarium Link.}

(Fig. 3Ca)

Colonies white, cottony, reverse yellowish pink. Mycelium hyaline, septate, profusely branched. Conidiophores hyaline, short, bearing whorl of phialides. Macroconidia hyaline, canoe shaped, 3-4 septate, $20-40 \times 3-5 \mu \mathrm{m}$.

4. Lasidiodiplodia theobromae (Pat.) Griff. \& Maubl, Bull. trimest. Soc. Mycol. Fr. 8:136 (1892).

(Fig. 3Da-3Db)

Colonies greyish brown, cottony, reverse brownish black. Hyphae septate, branched, dark chocolate brown. Pycnidiaglobose, dark brown, ostiolated, $63-100 \mu \mathrm{m}$ wide. Conidiophores short, hyaline. Conidia dark brown, two-celled, ellipsoidal, $22-27 \times 14-18 \mu \mathrm{m}$.

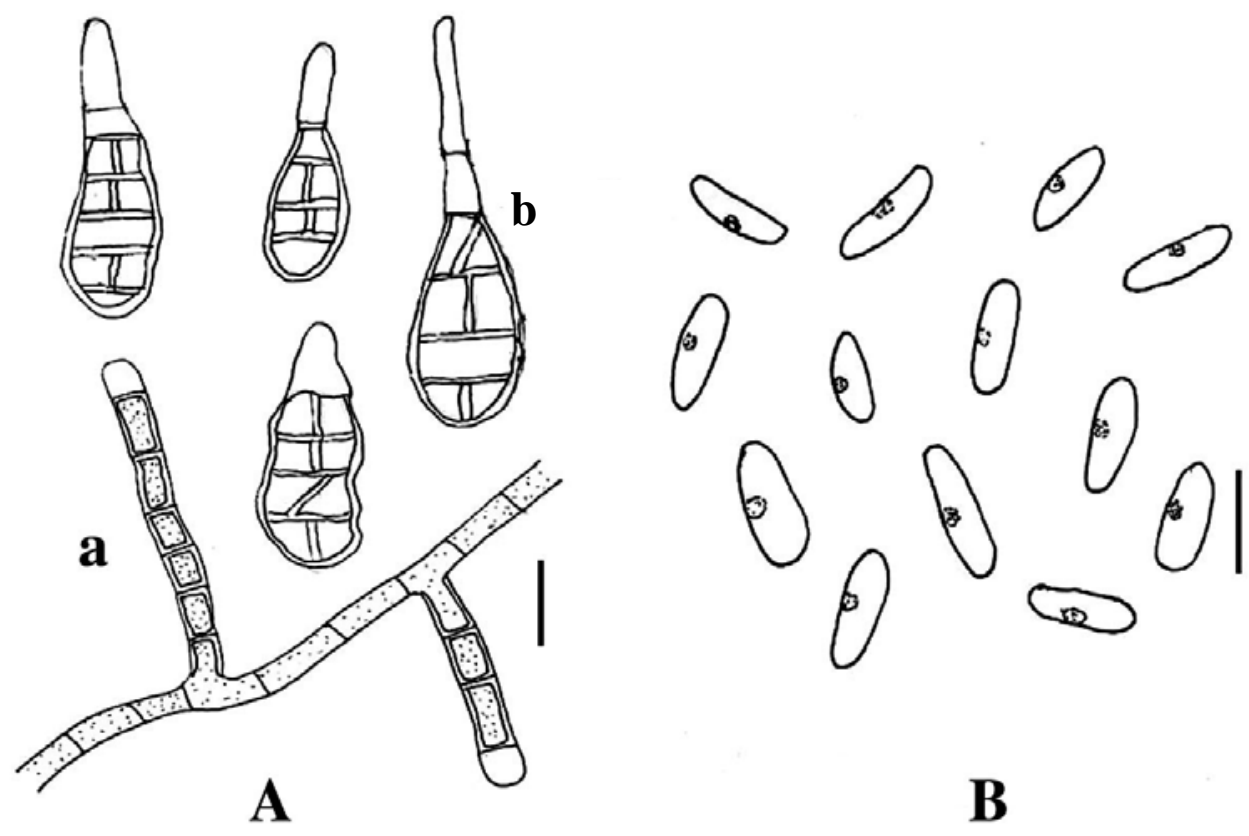

Fig. 2. A. Alternaria alternata: Aa. Conidiophores and Ab. Conidia; B. Colletotrichum orbiculare: Conidia. $($ Bar $=10 \mu \mathrm{m})$. 

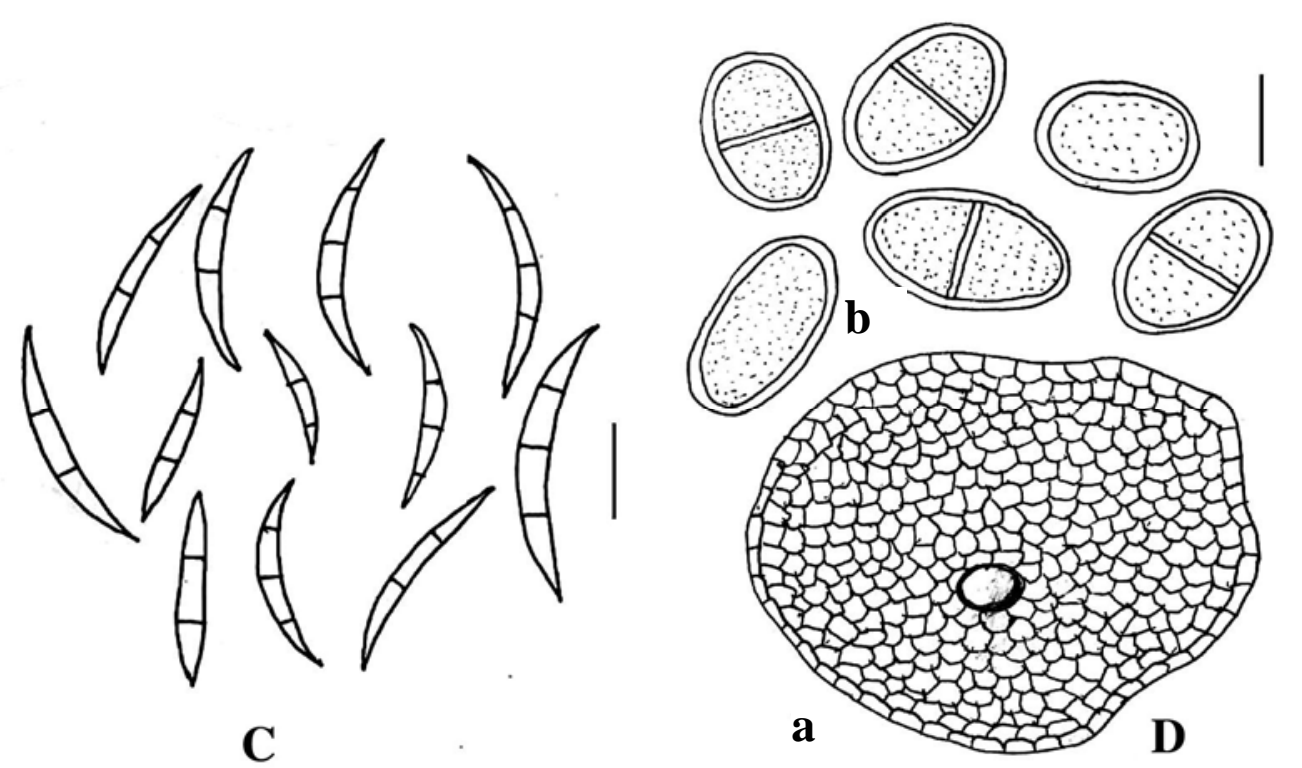

Fig. 3. C. Fusarium sp.: Ca. Conidia; D. Lasidiodiplodia theobromae: Da. Pycnidia and Db. Conidia. $(\mathrm{Bar}=10 \mu \mathrm{m})$.

\section{References}

Ahmed, Z.U., M.A. Hassan, Z.N. T. Begum, M. Khondker, S.M.H. Kabir, M.Ahmed, A.T.A. Ahmed, A.K.A. Rahman and E.U. Haque. (Eds.) 2008. Encyclopedia of Flora and Fauna of Bangladesh, Vol. 6. Angiosperms: Dicotyledons (Acanthaceae - Asteraceae). Bangladesh Asiat. Soc., Dhaka, pp. 1-408.

Barnett, H.L. and B.B.Hunter. 1972. Illustrated Genera of Imperfect Fungi. Burgess Pub. Co. U. S. A. pp. III +241 .

Booth, C. 1971. The genus Fusarium.Commonwealth Mycological Institute, Kew, Surrey, England, pp. 237.

Ellis, M.B. 1971. Dematiaceous Hyphomycetes. The Commonwealth Mycological Institute, England, pp. 608.

Gaikwad, A.P., D.M. Sawant and C.A. Nimbalkar. 2005. Perennation of Colletotrichum gloeosporioides, a causal agent of anthracnose of custard apple. Indian Phytopath. 58(2): 237-239.

Snowden, A.L. 2008. Post-harvest diseases and disorders of fruits and vegetables. General introduction and fruits by CRC press, Technology \& Engineering. 1: 320.

Spurr, H.W.J. and R.E. Wetly. 1972. Incidence of tobacco leaf microflora in relation to brown spot disease and fungicidal treatment. Phytopathol. 62: 916-920.

Sutton, B.C. 1980. The Coelomycetes fungi imperfecti with Pycnidia, Acervuli and Stromata. Commonwealth Mycological Institute, England. pp. 696. 